\title{
IMPLEMENTASI SUPERVISI AKADEMIK KEPALA SEKOLAH SEBAGAI UPAYA PEMBINAAN KINERJA GURU DI SDN MADULANG III OMBEN SAMPANG
}

\author{
Syaifudin ${ }^{1}$ \\ ${ }^{1}$ UPTD SDN Madulang III Omben Sampang \\ syaifudinsampang01@gmail.com
}

\begin{abstract}
Article History
Received [04|08|2020]

Revised [06|08|2020]

Accepted [15|08|2020]
\end{abstract}

\begin{abstract}
Teacher performance development is an effort aimed at helping and serving the knowledge, skills, attitudes, discipline, and quality of teachers in meeting the needs and welfare of teachers, so they have the will and ability to innovate, and always try to improve their performance to improve teaching and learning and achieving educational success. One of the activities to support the development of school teacher performance is academic supervision by the school principal. Academic supervision of the principal is an activity or a coaching process so that it can help the teacher to carry out activities in learning activities and administrative activities carried out by the teacher, thus making it run effectively. Achieve learning objectives. The purpose of this research is to find out how the school's academic supervision activities are carried out and to observe the improvement of teacher performance in SDN Madulang III Omben Sampang. This research was conducted at SDN Madulang III Omben Sampang using qualitative methods. The data collection techniques in this research were through observation, interviews, and documentation studies. The results showed that through several activities and training carried out regularly by the school, the academic supervision activities of the principal of SDN Madulang III Omben Sampang School had succeeded in promoting teacher performance. Also, the establishment of cooperation and communication between teachers and school principals is to support effective teacher training activities.
\end{abstract}

Keywords: ABSTRAK

Supervise, Kinerja

Pengembangan kinerja guru adalah upaya yang bertujuan untuk membantu dan melayani pengetahuan, keterampilan, sikap, disiplin, dan kualitas guru dalam memenuhi kebutuhan dan kesejahteraan guru, agar memiliki kemauan dan kemampuan untuk berinovasi, dan selalu berusaha meningkatkan kinerja mereka untuk meningkatkan pengajaran dan Belajar dan raih keberhasilan pendidikan. Salah satu kegiatan untuk mendukung pengembangan kinerja guru sekolah adalah supervisi akademik oleh kepala sekolah. Pengawasan akademik kepala sekolah adalah kegiatan atau proses pembinaan, sehingga dapat membantu guru untuk melakukan kegiatan dalam kegiatan pembelajaran dan kegiatan administrasi yang dilakukan oleh guru, sehingga membuatnya berjalan efektif. Mencapai tujuan pembelajaran. Tujuan dari penelitian ini adalah untuk mengetahui bagaimana kegiatan pengawasan akademik sekolah dilaksanakan dan untuk mengamati peningkatan kinerja guru di SDN Madulang III Omben Sampang. Penelitian ini dilakukan di SDN Madulang III Omben Sampang dengan menggunakan metode kualitatif. Adapun teknik pengumpulan data dalam penelitian ini melalui observasi, wawancara dan studi dokumentasi. Hasil penelitian menunjukkan bahwa melalui beberapa kegiatan dan pelatihan yang dilakukan secara teratur oleh sekolah, kegiatan pengawasan akademik kepala sekolah SDN Madulang III Omben Sampang Sekolah telah berhasil mempromosikan kinerja guru. Selain itu, terjalinnya kerja sama dan komunikasi antara guru dan kepala sekolah adalah untuk mendukung kegiatan pelatihan guru yang efektif. 


\section{PENDAHULUAN}

Di bidang pendidikan, terutama dalam menentukan keberhasilan siswa, guru memainkan peran yang sangat penting. peran guru tersebut mencakup tiga hal penting dalam pengembangan jati diri para peserta didik, yakni peningkatan kualitas sikap mental, peningkatan kapasitas intelektual dan peningkatan kapabilitas social (Sangadji, S.S, 2018). Oleh karena itu, para guru dituntut untuk berada dalam kondisi terbaik dalam pekerjaan mereka sebagai pendidik. Guru adalah komponen yang paling berpengaruh dalam menciptakan proses dan hasil pendidikan berkualitas tinggi (Kustiyah, 2017). Untuk meningkatkan tingkat pendidikan guru, persyaratan untuk meningkatkan kualitas guru juga meningkat. Meningkatkan kualitas guru akan konsisten dengan peningkatan kinerja guru (Rohimah, 2014).

Namun, dalam hal meningkatkan kinerja guru, ini bukan tugas yang mudah. Untuk meningkatkan kinerja guru, diperlukan perencanaan, pelaksanaan, pelatihan, evaluasi dan pengawasan (Damayanti, 2016). Tingkat profesional guru meliputi kemampuan berikut: menguasai materi, mengelola kegiatan belajar mengajar, mengelola kelas, mengelola media, menguasai dasar-dasar pendidikan, memahami interaksi antara mengajar dan belajar, menilai kinerja siswa, fungsi pemahaman, membimbing dan berkonsultasi dengan layanan, dan memahami manajemen sekolah.

Namun, dalam hal meningkatkan kinerja guru, ini bukan tugas yang mudah. Untuk meningkatkan kinerja guru, diperlukan perencanaan, pelaksanaan, pelatihan, evaluasi dan pengawasan (Handriyani, 2016). Tingkat profesional guru meliputi kemampuan berikut: menguasai materi, mengelola kegiatan belajar mengajar, mengelola kelas, mengelola media, menguasai dasar-dasar pendidikan, memahami interaksi antara mengajar dan belajar, menilai kinerja siswa, fungsi pemahaman, membimbing dan berkonsultasi dengan layanan, dan memahami manajemen sekolah .Dalam proses meningkatkan kualitas pembelajaran, meningkatkan kinerja guru menjadi sangat penting, yang kemudian akan berdampak pada kualitas lulusan dan mempengaruhi realisasi tujuan pendidikan nasional. Oleh karena itu, pemerintah terus bekerja pada berbagai hal untuk meningkatkan dan meningkatkan kemampuan guru sehingga guru dapat bekerja dengan baik. Ini termasuk memberikan peluang pendidikan tinggi, yang mengharuskan guru untuk menerima setidaknya gelar sarjana, memberikan pelatihan dan seminar, dan memberikan tunjangan sertifikasi(Purwanto, 2011).

Banyak faktor yang menyebabkan rendahnya kualitas guru Indonesia. Rendahnya gaji guru, terutama guru swasta, memaksa mereka untuk bekerja di luar jam mengajar untuk memenuhi kebutuhan sehari-hari mereka. Akibatnya, tugasnya sebagai guru menjadi tidak aktif (Ramadhan, 2019). Guru percaya bahwa selama ia memiliki gelar dan sertifikat, cukup membuktikan bahwa ia profesional, tanpa perlu terus belajar dan meningkatkan kinerja. Intensitas pengawas pendidikan yang rendah juga akan mempengaruhi kegiatan pengawasan akademik. Bahkan jika pengawas datang ke sekolah, mereka hanya bisa datang ke kantor kepala sekolah tanpa melihat ruang kelas. Beberapa kepala sekolah memahami peran mereka sebagai pengawas.

Oleh karena itu, sulit untuk menemukan kepala sekolah yang ingin datang ke kelas untuk melakukan kunjungan kelas untuk memainkan peran mereka sebagai instruktur akademik (Handriyani, 2016). Memang, pemerintah saat ini tidak pernah secara teratur 
melatih guru. Bahkan, pembinaan dan pelatihan harus dilakukan secara teratur untuk meningkatkan kemampuan dan kemampuan guru.

Oleh karena itu, kinerja pelatihan dan pelatihan guru adalah sesuatu yang harus dilaksanakan kepala sekolah. Untuk meningkatkan kinerja guru di sekolah, diperlukan rencana pembinaan yang menyeluruh, oleh karena itu melalui pembinaan semacam ini diharapkan kinerja guru juga akan meningkat(Desi Ratnasari, Roemintoyo, 2018).

Masalah pengembangan guru yang ditemukan di SDN Madulang III Omben adalah bagaimana masing-masing guru menanganinya, terutama peran yang berbeda. Ini membutuhkan pelaksana pelatihan untuk menerapkan gaya yang berbeda untuk setiap guru. Tetapi untuk pelatih instruktif, pelaksana dapat mengadopsi metode yang berlaku untuk semua guru(Ramadhan, 2019).

Masalah ini mempengaruhi kinerja guru, karena guru harus selalu mengembangkan kemampuan mereka dan harus kompeten di bidangnya sehingga kinerja guru terbaik dapat dicapai dalam proses pengajaran nanti. Pengawasan penting bagi kepala sekolah karena kepala sekolah bertanggung jawab atas kinerja guru (Pohan, 2017).

Berdasarkan fenomena dan masalah di atas, penulis menyadari bahwa pentingnya kegiatan pengawasan kepala sekolah akan berdampak pada kinerja guru, oleh karena itu, penulis tertarik untuk penelitian lebih lanjut tentang judul pengembangan kinerja guru oleh kepala sekolah Omben Sampang Madulang III di Provinsi Jawa Timur melalui kegiatan pengawasan akademik.

\section{KAJIAN PUSTAKA}

Guru adalah pemimpin dalam keberhasilan pendidikan dan dianggap memainkan peran penting dalam mencapai tujuan pendidikan, yang mencerminkan kualitas pendidikan. Untuk mencapai tujuan pendidikan, guru dituntut untuk berprestasi dengan baik. Karena itu, kemampuan guru akan memengaruhi proses pendidikan sekolah (Sarumaha, n.d.).

Kinerja adalah terjemahan dari kata "Kinerja pekerjaan". Secara etimologis, kinerja berasal dari kata "kinerja", yang berarti tampilan atau implementasi.

Dapat dipahami dari uraian ini bahwa suatu pertunjukan adalah tindakan menunjukkan atau melakukan suatu kegiatan (Damayanti, 2016). Dengan demikian kinerja merupakan suatu kegiatan yang dilakukan oleh seseorang berdasarkan kemampuan yang dimiliki dan dapat dipengaruhi oleh berbagai faktor, salaah satunya adalah kompensasi (Jelita, dkk. 2020)

Kinerja juga dapat dikatakan sebagai kemampuan seseorang untuk memenuhi kewajibannya sesuai dengan tugas yang diberikan kepadanya. Kinerja adalah kegiatan yang dilakukan sesuai dengan harapan dan tujuan yang ditetapkan untuk menyelesaikan, menyelesaikan tugas dan tanggung jawab. Maka dapat dijelaskan bahwa kinerja adalah tindakan yang diambil seseorang untuk melakukan tugasnya sebagai karyawan sesuai dengan tugas yang diberikan (Imron, 2007).

Untuk menjaga agar tugas, peran, dan tanggung jawab guru selalu mutakhir, kepala sekolah senantiasa berupaya mendukung tugas mengajar guru melalui kegiatan berikut ini untuk terus mengembangkan kemampuannya (Metriza, 2016).

Profesionalisme guru harus terus ditingkatkan melalui bimbingan dan pengembangan profesi dan pekerjaan. Menurut Undang-Undang No. 14 tahun 2005 tentang Guru dan Dosen, Pasal 32 ayat 1, menetapkan bahwa pedoman dan pengembangan profesi guru adalah: 
a. Pengembangan dan pengembangan guru yang disebutkan dalam paragraf 1 mencakup kemampuan mengajar, kemampuan pribadi, kemampuan sosial dan kemampuan profesional.

b. Pengembangan dan pengembangan guru yang disebutkan dalam ayat 1 dilakukan melalui posisi fungsional.

c. Pengembangan dan pengembangan guru sebagaimana dimaksud dalam ayat 1 mencakup tugas, promosi pangkat dan promosi.

Dapat dijelaskan dari isi UU No. 14 tentang Guru dan Dosen pada tahun 2005 bahwa pengembangan guru di Indonesia mencakup pengajaran, pengembangan pribadi, sosial dan profesional. Sebagai pendidik, seorang guru harus bisa menguasai salah satu bidang pembelajaran yang menjadi dasar pembelajaran (Kustiyah, 2017).

Agar guru berkinerja baik, guru harus memenuhi persyaratan kualifikasi dan kemampuan (Kodariah, Herawan, Sutrasih, \& Indonesia, 2016). Guru sebagai pendidik harus memiliki keterampilan dasar untuk melakukan tugasnya. Kemampuan ini termasuk kemampuan mengajar, kemampuan profesional, kemampuan kepribadian dan kemampuan sosial. Dengan mengerahkan kemampuan ini, guru dapat diharapkan untuk melakukan tugasnya dengan sebaik-baiknya, dan proses kegiatan belajar mengajar dapat berjalan seperti yang diharapkan dan berjalan dengan lancar. Penjelasan dari empat kemampuan guru adalah sebagai berikut:

a. Kompetensi Pedagogik

Kemampuan mengajar meliputi memahami siswa, merancang dan menerapkan pembelajaran, mengevaluasi hasil pembelajaran, dan mengembangkan siswa untuk mewujudkan berbagai potensi mereka (Maunah, 2016).

Selain itu, dijelaskan pula bahwa kemampuan mengajar adalah kemampuan guru untuk mengelola pembelajaran siswa. Setiap guru harus mampu mencapai ini untuk mendidik kehidupan negara. Selain itu, dalam standar pendidikan nasional, interpretasi Pasal 28 (3) (a) menunjukkan bahwa kemampuan mengajar mengacu pada kemampuan untuk mengelola pembelajaran peserta didik, termasuk memahami siswa, merancang dan mengimplementasikan pembelajaran, mengevaluasi hasil pembelajaran, dan pelatihan. Kemampuan para peserta. Biarkan siswa mencapai potensi penuh mereka (Desi Ratnasari, Roemintoyo, 2018).

Kesimpulan yang dapat ditarik adalah bahwa kemampuan mengajar semacam ini adalah tempat realisasi diri di mana siswa memiliki berbagai potensi dan kemampuan.

b. Kompetensi Profesional

Kompetensi profesional dapat didefinisikan sebagai kemampuan guru untuk menguasai mata pelajaran mereka secara mendalam dan bagaimana mengkomunikasikannya dengan baik kepada siswa (Syahrudin, Ernawati, Abdul Rahman, dan Sihes, 2013). Guru harus menguasai kemampuan untuk menyelesaikan tugas mengajar utama (Mulyasa , 2007), kemampuan terkait erat dengan penyesuaian tugas guru.

Ada juga definisi kemampuan profesional, yaitu penguasaan materi pembelajaran yang luas dan mendalam, termasuk penguasaan materi kurikulum mata pelajaran sekolah dan bahan-bahan ilmiah yang membuat materi gelap, serta penguasaan struktur dan metode ilmiah. 
Berdasarkan konsep dua kemampuan profesional ini, dapat dipahami bahwa kemampuan ini membutuhkan guru untuk memiliki pemahaman yang mendalam tentang mata pelajaran ini dan dapat menyampaikannya dengan benar kepada siswa.

c. Kompetensi Kepribadian

Dalam proses pembelajaran, kepribadian guru dapat memengaruhi minat peserta didik dalam mempelajari apa yang diajarkan guru. Jika gurunya menyenangkan, siswa akan senang setelah belajar. Suasana menyenangkan yang dirasakan siswa akan mendorong proses pembelajaran, terutama untuk pencapaian tujuan pembelajaran dan keberhasilan pendidikan secara keseluruhan. Oleh karena itu, meningkatkan minat siswa dalam belajar adalah keputusan yang sangat penting dan tepat. Minat dan bakat siswa akan terus tumbuh. Para guru yang mengajar mereka memiliki kepribadian yang menyenangkan dan berwibawa.Guru membantu siswa menyingkirkan berbagai masalah yang dihadapi oleh siswa di kelas dan di luar kelas, dan bahkan berbagai masalah yang dihadapi oleh siswa dalam keluarga atau komunitas. Guru situs harus dapat memberikan solusi (Subianto, 2013).

Dalam hal ini, kekuatan dan kelemahan kepribadian guru pasti akan mempengaruhi kegiatan belajar mengajar siswa. Bahkan jika guru mengatur dengan senang hati dalam proses ini, itu juga dapat mempromosikan proses belajar siswa.

d. Kompetensi Sosial

Kompetensi sosial adalah kemampuan guru untuk berkomunikasi dan berinteraksi secara efektif dengan siswa, pendidik sebaya, pendidik, orang tua / wali siswa, dan masyarakat sekitar.

Mengenai interaksi antara guru dan siswa, keterampilan guru atau keterampilan sosial diperlukan. Menurut pakar psikologi pendidikan Gadner (Gadner, 1983), kemampuan sosial disebut kecerdasan sosial atau kecerdasan sosial. Kecerdasan sosial adalah salah satu dari 9 kecerdasan (logika, bahasa, musik, tubuh, uang, pribadi, alam, memasak) yang berhasil diidentifikasi oleh Gadner. Mengajar di kelas adalah ekspresi interaksi dalam proses komunikasi. Kompetensi sosial guru dianggap sebagai salah satu kemampuan atau kemampuan guru untuk mempersiapkan siswa untuk menjadi anggota masyarakat yang baik, dan salah satu kemampuan untuk mendidik dan membimbing masyarakat untuk menghadapi masa depan. Selain itu, guru dapat menciptakan kondisi belajar yang nyaman (Nafisah, 2016).

Keempat kemampuan ini harus menjadi milik guru. Harus memiliki kemampuan mengajar, karena itu berkaitan dengan kemampuan guru untuk memahami siswa dan mengelola pembelajaran. Selain itu, ada beberapa kemampuan profesional yang terkait dengan kemampuan guru untuk menguasai atau memahami mata pelajaran yang diajarkan. Yang kedua adalah kemampuan kepribadian, di sini, guru perlu memiliki kepribadian yang baik untuk merangsang minat siswa dalam belajar dan mempromosikan proses belajar. Yang terakhir adalah keterampilan sosial, di mana keterampilan komunikasi dan interaksi guru dapat menciptakan suasana belajar yang nyaman dan efektif.

Kepala sekolah adalah pemimpin, mereka memainkan peran lembaga pendidikan dalam memimpin sekolah dan bertindak sebagai pemimpin pendidikan. Kepala sekolah tidak hanya memiliki peran kepala lembaga pendidikan, tetapi selain posisi ini, kepala sekolah juga memainkan peran penting dalam pengembangan sekolah dengan menerapkan berbagai kebijakan. Roland S. Bart dalam buku Uhar Saputra menunjukkan bahwa kepala sekolah 
adalah kunci bagi sekolah yang berkualitas, penentu potensi atmosfer sekolah, dan faktor pendorong pertumbuhan guru.

Dari pengertian ini, dapat dilihat bahwa kepala sekolah bukan hanya penanggung jawab institusi pendidikan, tetapi juga memiliki tugas melaksanakan kebijakan yang dapat meningkatkan kualitas institusi pendidikan itu sendiri. Selain itu, kepala sekolah juga harus berfungsi sebagai pengawas atau pengawas untuk meningkatkan kinerja guru untuk mencapai kualitas guru yang diharapkan.

Menurut pemahaman Piet A. Sah (Subianto, 2013) pengawasan adalah upaya yang ditujukan untuk merangsang, mengoordinasi, dan terus membimbing pertumbuhan pribadi dan kolektif guru di sekolah sehingga mereka dapat lebih sadar dan efektif dalam mewujudkan semua fungsi pengajaran.

Pengawasan pada dasarnya bertujuan pada dua aspek, yaitu pengawasan akademik dan pengawasan manajemen. Fokus supervisi akademik adalah supervisi kegiatan belajar, dalam bentuk pembelajaran di dalam dan di luar kelas. Pengawasan manajemen menekankan pada pengamatan manajemen dan administrasi sekolah untuk mendukung pelaksanaan pembelajaran.

Pengawas akademik memiliki pendapat yang berbeda dari mereka yang berkualifikasi di bidangnya. Secara garis besar, pengertian pengawasan akademik terkait dengan kegiatan pengawasan terkait dengan kegiatan akademik. Namun, untuk mendapatkan pandangan yang lebih komprehensif terkait dengan pemahaman supervisi akademik, penulis berikut menjelaskan pandangan beberapa pakar.

Esensi supervisi akademik bukan untuk mengukur atau mengevaluasi kinerja guru, tetapi upaya untuk membantu guru mengembangkan kemampuan profesional mereka. Pengawasan akademik dilakukan oleh pengawas dan kepala sekolah.

Perilaku pengawasan yang membantu guru mengembangkan kemampuan mereka harus dirancang secara formal untuk memperjelas kapan rencana pengembangan dimulai dan berakhir. Desain mengambil bentuk rencana pengawasan akademik yang mengarah pada tujuan tertentu.

Karena pengawasan akademik merupakan tanggung jawab bersama antara pengawas dan guru, alangkah baiknya jika rencana itu dirancang bersama oleh pengawas dan guru. Tujuan akhir dari pengawasan akademik adalah untuk membuat para guru semakin mampu mempromosikan pembelajaran siswa.

Singkatnya, ketiga konsep di atas terutama berkaitan dengan kegiatan pengawasan akademik dalam hal timbal balik, strategi pengembangan dan pencapaian akhir.

Oleh karena itu, dapat disimpulkan bahwa pengawasan akademik adalah kegiatan guru atau proses bimbingan, sehingga dapat membantu kegiatan pembelajaran guru dan kegiatan manajemen administrasi untuk beroperasi secara efektif. Mencapai tujuan pembelajaran.

\section{METODE PENELITIAN}

Penelitian ini berfokus pada implementasi dan oleh karena itu tidak memiliki niat untuk menguji hipotesis atau eksperimen. Oleh karena itu, metode yang tepat untuk mempelajari masalah adalah metode kualitatif (Maunah, 2016).

Oleh karena itu, dapat dipahami bahwa metode kualitatif adalah metode untuk memeriksa keadaan alamiah dengan menggambarkan peristiwa-peristiwa dalam deskripsi. 


\section{Prosedur pengumpulan data}

Sangadji S, dkk (2019) menyebutkan bahwa teknik pengumpulan data penelitian terdiri dari obsevasi dan pengumpulan data dengan kuesioner, namun untuk mengumpulkan data yang diperlukan untuk penelitian ini, penulis menggunakan beberapa alat, termasuk: wawancara, observasi dan dokumen penelitian.

\section{Teknik Analisis Data}

Teknik analisis data yang digunakan dalam penelitian kualitatif adalah dua model, seperti model Mules dan Huberman dan model Spradley. Lakukan pengumpulan dan analisis data selama dan setelah penelitian. Model analisis data Miles and Huberman Sugiyono menunjukkan bahwa model dapat menggunakan tiga langkah: reduksi data, representasi data, dan kesimpulan.

\section{HASIL DAN PEMBAHASAN}

\section{Kegiatan Supervisi Akademik Kepala Sekolah}

Salah satu tugas kepala sekolah adalah merencanakan pengawasan akademik. Agar kepala sekolah melakukan tugasnya dengan benar, kepala sekolah harus memiliki kemampuan untuk merencanakan rencana pengawasan akademik.

Rencana pengawasan adalah panduan bagi kepala sekolah untuk memberikan panduan bagi pelaksanaan pengawasan, yang mencakup maksud dan tujuan pengawasan, yaitu guru. Tujuan pengawasan adalah untuk memungkinkan guru melaksanakan tugasnya dan menjadi guru yang profesional. Penelitian yang dilakukan di SDN Madulang III Omben membahas implementasi, teknik supervisi dan supervisi akademik selanjutnya. Berdasarkan hasil penelitian, diketahui bahwa supervisi akademik SDN Madulang III Omben bertujuan untuk memberikan bantuan kepada guru yang membutuhkan bimbingan dan tindak lanjut, dan untuk meningkatkan implementasi proses pembelajaran di kelas.

Hasil penelitian menunjukkan bahwa, berdasarkan penelitian teoritis, pengawas harus memenuhi prinsip pengawasan akademik, yaitu, kegiatan pengawasan yang sistematis, terencana dan berkesinambungan, dan pelaksanaan pengawasan di SDN Madulang III Omben berjalan dengan lancar. Selain melakukan pengawasan akademik, kepala sekolah juga harus memahami dan memahami teknik-teknik dalam pengawasan akademik.Kedua teknik ini bersifat pribadi, yaitu, teknik yang diterapkan oleh masing-masing guru dan teknik yang bersifat kolektif, yaitu, teknik yang melayani banyak orang.

\section{Kunjungan Kelas}

Kepala sekolah SDN Madulang III Omben melakukan kunjungan kelas reguler sebulan sekali untuk memantau kinerja masing-masing guru dan berkomunikasi dengan guru yang relevan ketika hambatan atau hambatan ditemukan dalam proses pembelajaran. Sejauh ini, kunjungan kelas telah dianggap sangat efektif, dan salah satu guru, guru peringatan, pernah menyampaikan ini sebagai guru kelas lima. Dia mengatakan bahwa kunjungan kelas ini sangat membantu, karena jika dia menemukan hambatan dalam proses pembelajaran, kepala sekolah akan memberikan solusi untuk masalah yang dia hadapi.

Berdasarkan hasil wawancara dengan kepala sekolah Madura No. 3, Omben mengatakan bahwa teknik pemantauan yang biasa dimulai dengan membuat rencana tahunan, silabus, dan rencana pelajaran, lalu memeriksa dan mengevaluasi salah satunya. Lalu ada teknologi kunjungan kelas, yang secara langsung memantau guru selama proses pengajaran, 
mengevaluasi banyak hal, dan kemudian memasukkan pendapat guru sehingga guru dapat beroperasi sesuai dengan instruksi sebelumnya selama pengawasan berikutnya.

Hasil penelitian menunjukkan bahwa kepala sekolah Madura III Mengben telah menunjukkan keterampilan yang unik, yaitu, melakukan kunjungan kelas sebagai kepala sekolah, yaitu, dengan mengamati atau mengamati metode pengajaran guru di kelas, untuk mendapatkan informasi tentang situasi aktual para guru. data. Ketika instruktur menemukan kekurangan guru, kunjungan kelas semacam ini juga sangat membantu bagi guru untuk meningkatkan kualitas mengajar siswa, instruktur akan memberikan saran, sehingga kegiatan belajar dan mengajar di masa depan akan lebih baik. Selain kunjungan kelas kepala sekolah Madulang III, Omben-Nisaa juga melakukan penyelidikan pribadi.Hal ini didasarkan pada penelitian teoritis yang ada, yaitu, pengawas dan guru bertemu untuk membahas masalah yang dihadapi oleh guru, tujuannya adalah untuk menyelesaikan kesulitan yang dihadapi. Akumulasi dan abaikan metode pengajaran yang lebih baik.

\section{Kegiatan Rapat Guru}

Pertemuan guru di SD Madben III Omben diadakan setiap bulan dan dipimpin langsung oleh kepala sekolah. Kegiatan pertemuan guru dirancang untuk menginformasikan panduan dan kebijakan sekolah terbaru dan rencana kegiatan pembelajaran yang inovatif. Selain itu, juga memberikan kesempatan bagi guru untuk berkomunikasi dan bertukar ide untuk mengatasi dan mengelola kesulitan di kelas. Pertemuan ini tidak hanya digunakan sebagai pengumuman hasil evaluasi kinerja guru bulan lalu, tetapi juga digunakan untuk memotivasi dan mengumumkan kinerja yang diharapkan pada bulan berikutnya.

Sebelum tahun ajaran baru, pertemuan guru rutin juga diadakan setiap semester dan setiap tahun. Menurut hasil wawancara saya, hampir semua guru SDN Madulang III Omben berpartisipasi dalam konferensi ini. Salah satu guru, Ibu Tuti Alawiyah, adalah kepala sekolah, dan mengatakan bahwa ia secara teratur berpartisipasi dalam konferensi dan acara yang diadakan di SD Madulang III Omben.

Pertemuan rutin ini diharapkan dapat meningkatkan tingkat profesional mereka dan bahan evaluasi sebagai guru untuk meningkatkan kinerja mereka. Berdasarkan hasil wawancara pribadi dengan guru-guru sekolah dasar Madulang III Omben terkait dengan pengawasan akademik kepala sekolah, dan sampel survei dari 12 guru, hasil berikut diperoleh:

Menurut hasil wawancara pribadi, data yang diperoleh di atas adalah waktu / jadwal kegiatan pengawasan yang ditetapkan oleh kepala sekolah dan guru, dengan skor maksimum 10 poin (selalu). Ini berarti bahwa kepala sekolah harus selalu melibatkan guru dalam merumuskan rencana pengawasan akademik, yang didasarkan pada Keputusan Menteri Pendidikan No. 2009 No. 39, yang menetapkan ruang lingkup pengawasan akademik termasuk: a) rencana pelatihan guru, implementasi dan evaluasi proses pembelajaran , B) Mengawasi penerapan standar konten, c) Mengawasi penerapan standar proses, d) Mengawasi penerapan standar kemampuan kelulusan, e) Mengawasi penerapan standar fakultas dan staf, dan f) Mengawasi penerapan standar evaluasi.

Mengingat kepala sekolah, ketika guru tidak dapat melaksanakan hasil yang ditentukan dari 9 poin (selalu) dan 3 poin (biasanya), mereka bersedia menjadwal ulang kegiatan pengawasan akademik, karena kepala sekolah selalu menyediakan untuk setiap guru yang tidak dapat secara akademik diawasi oleh kepala sekolah berikan kesempatan. Untuk 
memperbaiki kekurangan yang ditemukan oleh guru dalam proses pengawasan akademik, sekolah akan mengizinkan kepala sekolah untuk mengunjungi kelas kelas 6 tertinggi (selalu), 5 (sering), 1 (kadang-kadang) pada waktu berikutnya, yang berarti bahwa banyak guru dan kepala sekolah menghadiri kelas Kadang-kadang saya merasa nyaman dengan kedatangan kepala sekolah, dan beberapa guru merasa tidak nyaman ketika kepala sekolah ada di kelas.

\section{Pembinaan Kinerja Guru}

Beberapa guru percaya bahwa bimbingan tentang kinerja guru sangat bermanfaat bagi pengembangan profesional guru. Guru SDN Madulang III Omben, Ibu Maya (Ibu Maya) merasakan hal ini, dia adalah guru bahasa Inggris. Seperti yang kita semua tahu, konseling guru mengacu pada serangkaian bantuan kepada guru, terutama bantuan dalam bentuk layanan profesional yang diberikan oleh kepala sekolah, pemilik sekolah, pengawas dan pengawas lainnya untuk meningkatkan proses pembelajaran dan hasil siswa.

Oleh karena itu, di bawah bimbingan kinerja guru, kualitas guru ditingkatkan dalam proses kegiatan belajar mengajar. Selain itu, melalui pelatih seperti itu, guru dapat menggunakan apa yang sudah dapat mereka lakukan dalam setiap proses pembelajaran dalam pelatihan untuk mencapai tujuan pembelajaran yang diinginkan. Melalui pelatihan ini, ini memberikan manfaat bagi pengembangan profesional guru mereka. Pelatihan yang diselenggarakan oleh kepala sekolah SDN Madulang III Omben untuk meningkatkan kinerja guru meliputi pelatihan bahasa Inggris, pelatihan Tahin, dan partisipasi dalam kegiatan konferensi guru.

Menurut hasil wawancara saya dengan kepala sekolah SDN Madulang III Omben, untuk meningkatkan kinerja guru, beberapa kegiatan pembinaan telah dilakukan:

Ada banyak program pelatihan yang sudah beroperasi dan direncanakan untuk dilaksanakan secara teratur, misalnya, pengawasan semua guru, pelatihan guru, seperti pelatihan bahasa Inggris, pelatihan Daxin, dan kemudian ada program HOTS (Keterampilan Berpikir Lain), pelatihan Dirancang untuk guru untuk mengajukan pertanyaan, ada kegiatan rutin lainnya, seperti pertemuan guru setiap bulan, dan seminar diadakan di sekolah dan di luar kampus sesuai dengan kebutuhan para guru yang akan les. Anda juga dapat mengamati dan mempersiapkan pelatih kinerja dari kelas, karena di sini, guru tidak hanya memiliki tugas mengajar, tetapi juga bagaimana guru membuat siswa tertarik dan meniru apa yang guru ajarkan.

Dari hasil demonstrasi, kita bisa tahu bahwa pelatihan itu dilaksanakan sesuai rencana. Ini hanya untuk mengembangkan kualitas profesional guru dalam proses kegiatan mengajar.

Bimbingan di sini tidak berfokus pada guru itu sendiri, tetapi bagaimana kepala sekolah mengajari tujuan dan melaksanakannya sesuai dengan harapan. Kepala sekolah melakukan pengawasan klinis di sini, yaitu, sebagai pengawas, kepala sekolah secara langsung mengamati metode pengajaran guru, dan melakukan diskusi umpan balik antara guru dan kepala sekolah. Hal ini dilakukan untuk mendapatkan umpan balik tentang perasaan guru dalam proses, jadi jika masalah ditemukan, solusi dapat ditemukan untuk memperbaikinya, jika hal-hal positif ditemukan, mereka dapat dibagi dengan guru lain yang mengalami kesulitan.

Dalam proses pengembangan kinerja guru, hambatan atau hambatan pasti akan dihadapi. Kepala SDN Madulang III Omben mengungkapkan hal ini: 
Selama waktu ini, hampir tidak ada kendala, dan guru dapat mengikuti dan memahami rencana bimbingan yang dibuat sejak awal. Biasanya masalahnya hanya waktu atau waktu kehadiran guru, jika ada jadwal bimbingan, guru yang bersangkutan tidak bisa hadir. Kemudian, solusi yang dapat kami berikan akan dijadwal ulang untuk arahan ulang.

Dapat dilihat dari pidatonya bahwa batasan yang dirasakan terkait dengan pengaturan kegiatan pembinaan itu sendiri, apakah itu di dalam sekolah atau pelatihan atau seminar yang dilakukan di sekolah. Apa yang dapat dilakukan kepala sekolah sebagai pengawas adalah menjadwal ulang waktu dengan masing-masing guru. Penataan ulang bisa dilihat dari kegiatan pembinaan yang dilakukan. Jika dikelola oleh sekolah (internal), itu dapat direncanakan kapan saja, tetapi jika dilakukan oleh organisasi eksternal, itu akan dikonfirmasi terlebih dahulu dengan pihak-pihak terkait yang tidak dapat berpartisipasi dalam guru. Di sini, kepala sekolah harus menemukan cara terbaik agar semua guru mendapat manfaat dari kegiatan pembinaan yang diadakan.

\section{KESIMPULAN}

Berdasarkan hasil penelitian yang dilakukan, dapat disimpulkan bahwa dengan mengawasi kegiatan akademik kepala SDN Madulang III Omben untuk meningkatkan kinerja guru sebagai berikut: (1) Meningkatkan kinerja guru SDN Madulang III Omben melalui kegiatan reguler dan terencana. Instruksi rutin meliputi pelatihan tahsin dan pelatihan bahasa Inggris. (2) Kegiatan pengawasan akademik kepala sekolah untuk meningkatkan kinerja guru termasuk kunjungan kelas dan pertemuan guru. Saat melakukan kegiatan supervisi akademik, kepala sekolah menentukan jadwal untuk supervisi, mengunjungi para guru untuk diawasi, menganalisis dan mengisi alat-alat, dan memperoleh pendapat tentang melakukan kegiatan pengawasan dari para guru. Berdasarkan kesimpulan di atas, dapat disimpulkan bahwa kinerja guru telah berhasil ditingkatkan melalui kegiatan pengawasan akademik kepala sekolah SDN Madulang III Omben, dan sekolah telah secara teratur melakukan banyak kegiatan dan pelatihan. Selain itu, terjalinnya kerja sama dan komunikasi antara guru dan kepala sekolah merupakan masalah pendukung sehingga kegiatan peningkatan kinerja guru dapat dilakukan secara efektif. 


\section{DAFTAR PUSTAKA}

Damayanti, W. (2016). Peningkatan Mutu Kinerja Guru Melalui Supervisi Akademik Di Smk Negeri 1 Salatiga Menghadapi PKG 2016 ( Solusi Perubahan dengan Gabungan Model Supervisi Akademik Artistic Model dan Cooperative Development Model ). Jurnal Pendidikan Ilmu Sosial, 26(1), 80-86.

Desi Ratnasari, Roemintoyo, W. (2018). Implementasi teknik supervisi akademik kepala sekolah terhadap pendidik di sekolah dasar untuk menghadapi era digital. Jurnal Manajemen Dan Supervisi Pendidikan, 3(November), 1-4.

Handriyani, P. (2016). Supervisi Akademik Kepala Sekolah Dalam Meningkatkan Kompetensi Profesional Guru PAI (Studi Kasus di SD se-Kecamatan Sregen Tahun 2016) Oleh:

Imron, A. (2007). Penelitian Tindakan Sekolah Untuk Kepala Sekolah Dalam Rangka Peningkatan Kinerja Pembelajaran.

Jelita, Dahlan, D., Bobi , R., \& Sangadji, S. S. (2020). The Work Motivation Effect of Meter Recording Employees in Drinking Water Company at Tidore City. Indonesian Journal of Agribusiness Management and Economic Sciences , 1(1), 10-14. Retrieved from http://ejournal.univ-nuku.ac.id/index.php/IJAMES/article/view/11

Kodariah, W., Herawan, E., Sutrasih, C., \& Indonesia, U. P. (2016). Supervisi Akademik Kepala Sekolah, Motivasi Berprestasi Guru Dan Kinerja Mengajar Guru. Jurnal Administrasi Pendidikan, Vol.XXIII(2), 123-133.

Kustiyah. (2017). Meningkatkan Kinerja Guru Melalui Supervisi Akademik Kepala Sekolah Dengan Pendekatan Individual Di Sd Candi 01 Kecamatan Candisari Kota. MALIH PEDDAS, 7, 11-20.

Maunah, B. (2016). Implementasi Pendidikan Karakter Dalam Pembentukan Kepribadian Holistik Siswa. Jurnal Pendidikan Karakter, (1), 90-101. https://doi.org/10.21831/jpk.v0i1.8615

Metriza. (2016). Supervisi Akademik Oleh Kepala Sekolah Dalam Rangka Meningkatkan Profesional Mengajar Guru.

Nafisah, I. (2016). Pendidikan Karakter Dalam Keluarga (Studi Kasus Orang Tua Siswa Sekolah Dasar). Naskah Publikasi UIN Maulana Malik Ibrahim Malang, 1-72.

Pohan, N. (2017). Peran Supervisi Kepala Sekolah Terhadap Pelaksanaan Tugas Pokok Guru: Penelitian Tindakan Sekolah. JPD: Jurnal Pendidikan Dasar, 1(3), 132-139.

Purwanto, S. (2011). Pengembangan Lagu Model Sebagai Media Pendidikan Karakter Bagi Anak Usia Din.

Ramadhan, E. (2019). Pembinaan Kinerja Guru Melalui Kegiatan Supervisi Akademik Kepala Sekolah Di Sd An-Nisaa' Tangerang Selatan 2019 M / 1440 H supervisi Akademik Kepala Sekolah Di Jurusan Manajemen Pendidikan Fakultas Ilmu Tarbiyah Dan Keguruan Universitas Islam Negeri Syarif Hidayatullah. 
Rohimah. (2014). Pelaksanaan Supervisi Klinis Di Sekolah Upaya Peningkatan Kinerja Guru Pendidikan Agama Islam Sekolah Dasar Kecamatan Jaten Kabupaten Karanganyar.

Sangadji, S., Suhardi, S., \& Ali, C. P. M. (2019). Pengaruh Bauran Pemasaran terhadap Keputusan Pembelian Sagu Rasa pada Gabungan Kelompok Tani Tagafura di Kelurahan Jaya Kota Tidore Kepulauan. Optimal: Jurnal Ekonomi dan Kewirausahaan, 13(2), 142157.

Sangadji, S. S. (2018). Peran Strategis Perguruan Tinggi dalam Perspektif Pembangunan Daerah Di Provinsi Maluku Utara. https://doi.org/10.31219/osf.io/xf9kg

Sarumaha, D. (n.d.). Peningkatan Kinerja Guru Dalam Pembelajaran Melalui Supervisi Akademik Berkesinambungan Di Smk Negeri 2 Fanayama, Kecamatan Fanayama, Kabupaten Nias Selatan.

Subianto, J. (2013). Peran Keluarga, Sekolah, Dan Masyarakat Dalam Pembentukan Karakter Berkualitas. Edukasia: Jurnal Penelitian Pendidikan Islam, 8(2), 331-354. https://doi.org/10.21043/edukasia.v8i2.757 